\title{
Impact of COVID-19 on academic activities of final year nursing students: a Zambian reflection
}

\author{
Kennedy Mwila ${ }^{1 *}$, Florence Kalolo ${ }^{2}$, Steward Mudenda ${ }^{3}$, Christabel Nangandu Hikaambo $^{3}$
}

\author{
${ }^{1}$ Department of Educational Administration and Policy Studies, ${ }^{3}$ Department of Pharmacy, School of Health Sciences, \\ University of Zambia, Lusaka, Zambia \\ ${ }^{2}$ Department of Nursing Sciences, Texila American University, Lusaka, Zambia
}

Received: 07 May 2021

Accepted: 29 May 2021

\section{*Correspondence:}

Kennedy Mwila,

Email: mwilakennedy@yahoo.com

Copyright: () the author(s), publisher and licensee Medip Academy. This is an open-access article distributed under the terms of the Creative Commons Attribution Non-Commercial License, which permits unrestricted non-commercial use, distribution, and reproduction in any medium, provided the original work is properly cited.

\begin{abstract}
Background: The novel coronavirus disease 2019 (COVID-19) has had many impacts on the education sector. The pandemic has had negative impacts on the academic activities of nursing students globally. Therefore, we assessed the impact of the COVID-19 on final year nursing students' academic activities in Lusaka and Mufulira districts of Zambia.

Methods: This was a cross-sectional study that employed quantitative methods using a structured questionnaire among 196 final year nursing students from 1 August 2020 to 30 September 2020. Data were analysed using the statistical package for social sciences (SPSS) version 21.

Results: A female predominance $(67.9 \%)$ and a response rate of $86 \%$ were obtained. Many students strongly agreed $(32.7 \%)$ and agreed $(20.4 \%)$ that they did not complete their course work resulting in some concepts being poorly taught, $86.1 \%$ strongly agreed that they had delayed final examinations, and $51.5 \%$ strongly agreed that they did not do their clinical attachments. Students strongly disagreed $(40.3 \%)$ that the e-library and wireless facilities in their school were well-stocked. Hence, this resulted in some students $(40.3 \%)$ missing class lessons and assessments.

Conclusions: The COVID-19 epidemic has negatively affected the academic activities of nursing students in Zambia. Ministries responsible for education must put in place measures that will mitigate the impact of COVID-19 on the education sector. Schools must adapt to the changes in the way of conducting learning and assessment sessions. Finally, schools must improve on their e-library and wireless facilities to effectively support online learning.
\end{abstract}

Keywords: Coronavirus disease, COVID-19, Academic activities, Pandemic, Nursing students, Online infrastructure, Education sector Zambia

\section{INTRODUCTION}

The ongoing novel coronavirus disease (COVID-19) pandemic emerged from China in 2019. ${ }^{1}$ COVID-19 is a respiratory tract disease that is transmitted from person to person through droplets from an infected person who coughs or sneezes. ${ }^{2,3}$ The pandemic has caused a lot of economic and education instability throughout the world. ${ }^{4,5}$ Therefore, this has resulted in extraordinary measures to contain the pace or reduce the impact of COVID-19.,7 The COVID-19 pandemic has affected educational systems worldwide, leading to partial and total closure of schools, universities and colleges. ${ }^{8}$ As of mid-April 2020, approximately 1.723 billion learners were affected due to school closures in response to the pandemic. ${ }^{9}$ According to UNESCO monitoring, 191 countries implemented nationwide closures as well as local closures, impacting about $98.4 \%$ of the world's 
student population. ${ }^{10}$ School closures may have an impact on the students, teachers and families, economic and societal consequences. ${ }^{11,12}$

It was also noted that nursing schools were not spared by the closures because of the COVID-19 outbreak. ${ }^{13,14}$ Many medical programs were struggling to find ways to meet students' clinical experiences and run online classes. $^{15}$ In many countries, governments had implemented lockdown measures to curb the spread of COVID-19.16-18 Previous studies have shown that the closure of educational institutions is an effective strategy for breaking the critical transmission chain during the pandemic. ${ }^{19-22}$

The COVID-19 pandemic has caused negative consequences on students' academic study, including learning interruptions, disruption to assessment, and the impact is more severe on students from disadvantaged backgrounds. ${ }^{15}$ The nationwide closure of educational institutions, i.e. schools, colleges, and universities has adversely impacted over $60 \%$ of the world's student population. ${ }^{23}$ The delay in re-opening educational institutions can negatively affect the mental state and academic growth of students. ${ }^{24}$ The long-time home quarantine period caused disturbance and deterioration in students' study habits and performance of work, which eventually resulted in the growth of stress and dysfunctional learning behaviours. ${ }^{25}$ Further, it has been observed that students and the general population have experienced psychological challenges as a result of COVID-19; this could affect their academic performance., ${ }^{4,26}$ Zambia, a country in the Centre of the Southern African Region only had its first two cases reported on the $18^{\text {th }}$ of March $2020 .^{27,28}$ This resulted in the Zambian government announcing that all schools, colleges and universities were to be closed on Friday the $20^{\text {th }}$ of March $2020 .{ }^{29}$ Due to the premature closure of education institutions, Colleges and Universities had employed technologically driven learning and assessment through online platforms such as Moodle and the opensource learning management (LMS) framework. Built on pedagogical principles, Moodle was used in learning institutions, workplaces and other sectors for blended learning, distance education, flipped classroom and other e-learning projects. ${ }^{30}$ The closure of learning institutions necessitated by the need to curtail the spread of COVID19, should not completely deny learners access to learning. Therefore, our study focused on assessing the impact of COVID-19 on the academic activities of final year nursing students in Lusaka and Mufulira districts of Zambia.

\section{METHODS}

\section{Study design and sites}

This was a cross-sectional study that was conducted using a structured questionnaire in which quantitative methods were employed. The study was conducted in the Lusaka and Copperbelt provinces of Zambia, specifically in Lusaka and Mufulira districts from 1 August 2020 to 30 September 2020. The study was conducted at Lusaka colleges of nursing and Midwifery, Lusaka Apex medical university and Mufulira school of nursing.

\section{Data collection}

Data were collected using a structured questionnaire that was pre-tested among 12 final year nursing students. The pre-test was done to determine the accuracy, consistency, appropriateness, and easiness.

The questionnaire was used to collect data on the sociodemographic characteristics of the participants, effects of COVID-19 on academic activities and the suggested measures to effectively support the academic progression of the nursing students. A Likert scale was used to measure the responses on the effects of COVID19 on the academic activities of final-year nursing students. The responses included; agree, disagree, neutral, strongly agree, and strongly disagree.

\section{Sample size determination and sampling technique}

A sample size of 207 final year nursing students was determined using Yamane's formula; ${ }^{31}$

$$
\mathrm{n}=\frac{N}{1+N(e)^{2}}
$$

We used a research population of 425 final-year nursing students from the three nursing schools, and a margin of error of $5 \%$ at $95 \%$ confidence level. We took into consideration a $10 \%$ loss or non-response. We randomly circulated 228 questionnaires of which 196 were completed by the final-year nursing students. A purposive sampling technique was employed in our study.

\section{Inclusion criteria}

All the final-year nursing students studying at Lusaka College of Nursing and Midwifery, Lusaka Apex medical university and Mufulira school of nursing and Midwifery were included in the study

\section{Exclusion criteria}

All final-year nursing students who did not provide consent to participate in the study were excluded from the study.

\section{Data analysis}

The collected data were entered into a Microsoft excel sheet and imported into the statistical package for social sciences (SPSS) version 21.0 for analysis. The results were presented in form of tables. 


\section{RESULTS}

\section{Sociodemographic characteristics}

A response rate of $86 \%$ was achieved. The study found a female predominance $(67.9 \%)$ of which the majority $71(36.2 \%)$ came from the Lusaka College of Nursing and Midwifery as shown in (Table 1).

Most students strongly agreed that COVID-19 caused failure to complete course content (32.7\%), concepts poorly taught $(41.3 \%)$, delayed their examinations $(86.1 \%)$, and prevented students from doing their clinical attachments $(51.5 \%)$ (Table 2). Most students strongly disagreed $(40.3 \%)$ that their school has an effective elibrary. The students strongly agreed $(40.3 \%)$ that some students missed assessments and lectures due to poor access to the internet and they strongly disagreed (36.7\%) that their school has effective wireless facilities to be used for online learning (Table 3).

Table 1: Characteristics of participants $(n=196)$.

\begin{tabular}{|lll|c|}
\hline Variable & Category & Frequency & $\%$ \\
\hline \multirow{2}{*}{ Sex } & Male & 63 & 32.1 \\
\cline { 2 - 4 } & Female & 133 & 67.9 \\
\hline Name of & LCNM & 71 & 36.2 \\
\cline { 2 - 4 } & LAMU & 99 & 50.5 \\
\cline { 2 - 4 } & MSNM & 26 & 13.3 \\
\hline
\end{tabular}

LCNM=Lusaka College of Nursing and Midwifery; LAMU=Lusaka Apex Medical University; MSNM=Mufulira school of nursing and Midwifery

Table 2: Effects of COVID-19 on course work coverage and timely completion of studies.

\begin{tabular}{|llllll|}
\hline Variables & $\begin{array}{l}\text { Responses } \\
\text { SD }(\%)\end{array}$ & D (\%) & N (\%) & A (\%) & SA (\%) \\
\hline $\begin{array}{l}\text { COVID-19 has caused failure to complete } \\
\text { course content for final year nursing students }\end{array}$ & $30(15.3)$ & $46(23.5)$ & $16(8.1)$ & $40(20.4)$ & $64(32.7)$ \\
\hline $\begin{array}{l}\text { COVID-19 has caused some concepts to be } \\
\text { poorly taught }\end{array}$ & $20(10.2)$ & $24(12.2)$ & $17(8.7)$ & $54(27.6)$ & $81(41.3)$ \\
\hline $\begin{array}{l}\text { COVID-19 has caused a delay in the } \\
\text { examination of the final year students }\end{array}$ & $6(3.1)$ & $6(3.1)$ & $8(4.1)$ & $7(3.6)$ & $169(86.1)$ \\
\hline $\begin{array}{l}\text { COVID-19 has prevented final year nursing } \\
\text { students from going for clinical attachments }\end{array}$ & $17(8.7)$ & $10(5.1)$ & $26(13.3)$ & $42(21.4)$ & $101(51.5)$ \\
\hline
\end{tabular}

$\mathrm{SD}=$ strongly disagree; $\mathrm{D}=$ disagree; $\mathrm{N}=$ neutral; $\mathrm{A}=$ agree; $\mathrm{SA}=$ strongly agree

Table 3: Nature of online infrastructure in supporting effective assessments of final-year students during the COVID-19 pandemic.

\begin{tabular}{|c|c|c|c|c|c|}
\hline \multirow{2}{*}{ Variables } & \multicolumn{5}{|c|}{ Responses } \\
\hline & SD $(\%)$ & D $(\%)$ & $\mathbf{N}(\%)$ & $\mathrm{A}(\%)$ & SA (\%) \\
\hline Our school is well stocked with the e-library & $79(40.3)$ & $35(17.9)$ & $30(15.3)$ & $40(20.4)$ & $12(6.1)$ \\
\hline $\begin{array}{l}\text { Some students miss assessments and lectures } \\
\text { due to poor access to internet }\end{array}$ & $18(9.2)$ & $14(7.1)$ & $31(15.8)$ & 54 (27.6) & 79 (40.3) \\
\hline $\begin{array}{l}\text { The school has effective wireless facilities to } \\
\text { be used for online lessons }\end{array}$ & $72(36.7)$ & $25(12.6)$ & 35 (17.6) & $32(16.5)$ & $32(16.5)$ \\
\hline
\end{tabular}

$\mathrm{SD}=$ strongly disagree; $\mathrm{D}=$ disagree; $\mathrm{N}=$ neutral; $\mathrm{A}=$ agree; $\mathrm{SA}=$ strongly agree

Table 4: Measures to be put in place by schools to address the academic progression of nursing students.

\begin{tabular}{|c|c|c|c|c|c|}
\hline \multirow{2}{*}{ Variables } & \multicolumn{5}{|c|}{ Responses } \\
\hline & SD (\%) & D $(\%)$ & $\mathbf{N}(\%)$ & $\mathrm{A}(\%)$ & SA (\%) \\
\hline $\begin{array}{l}\text { The school should provide face masks for } \\
\text { students in examination classes during the } \\
\text { pandemic }\end{array}$ & $12(6.3)$ & $20(10.1)$ & $10(5.1)$ & $52(26.6)$ & $102(51.9)$ \\
\hline $\begin{array}{l}\text { The school should provide hand sanitisers to } \\
\text { students during the pandemic }\end{array}$ & $25(12.7)$ & $2(1.3)$ & $15(7.6)$ & $62(31.6)$ & $92(46.8)$ \\
\hline $\begin{array}{l}\text { Lecturers should do computer refresher } \\
\text { courses to conduct online lectures effectively }\end{array}$ & $5(2.5)$ & $10(5.1)$ & $30(15.2)$ & $79(40.5)$ & $72(36.7)$ \\
\hline $\begin{array}{l}\text { The school should have a well-stocked e- } \\
\text { library that will improve online learning }\end{array}$ & $8(4.1)$ & $0(0.0)$ & $13(6.3)$ & $79(40.5)$ & $96(49.2)$ \\
\hline
\end{tabular}

$\mathrm{SD}=$ strongly disagree; $\mathrm{D}=$ disagree; $\mathrm{N}=$ neutral; $\mathrm{A}=$ agree; $\mathrm{SA}=$ strongly agree 
Most students expected their school to provide face masks $(51.9 \%)$ and hand sanitisers (46.8\%). Most students suggested that their lecturers should do computer refresher courses $(40.5 \%)$ and the school to improve on stocking of the e-library $(49.2 \%)$ to improve on online learning (Table 4).

\section{DISCUSSION}

We assessed the impact of COVID- 19 on the academic activities of final year nursing students in Lusaka and Mufulira Districts of Zambia. Our findings show that most students strongly agreed that COVID-19 caused failure to complete course content (32.7\%), concepts poorly taught $(41.3 \%)$, delayed their examinations $(86.1 \%)$, and prevented students from doing their clinical attachments $(51.5 \%)$. These results, therefore, mean that the academic performance of students could be affected by such disturbances. These findings were in tandem with the UNESCO 2020 report that deduced that school closures as a result of COVID-19 have a huge impact on the education sector though it was difficult to measure the specific impact. ${ }^{23}$

In Egypt, Shehata et al similarly reported that students experienced challenges with regards to learning clinical skills due to a lack of clinical placements. ${ }^{32}$ Evidence has shown that University and College students were worried about their academic progress because of COVID-19 and the introduction of online learning. ${ }^{33,34}$ Similarly, a study by Charles et al on alcohol abuse among college students during the COVID pandemic reported that students experienced significant educational disruptions as the pandemic interfered with their academic functioning. ${ }^{35}$ This is because the closure of tertiary-level educational institutions suspended face-to-face teaching-learning sessions hence interrupting the regular flow of academic programs. ${ }^{34,36}$ Some schools had to postpone or cancel the students' examinations. ${ }^{37}$ This can lead to an impact on the mental health and academic performance of the students. ${ }^{4,26,33,38}$

Current study revealed that students' periods of clinical attachments were disrupted and shortened due to the pandemic. Similarly, another study reported that the clinical placements of nursing students were cancelled, despite the future nurses being among the frontline workers. ${ }^{15}$ The lack of an effective clinical learning environment for student nurses prevents them from effective learning and growth. ${ }^{39}$ As a result, the growth and development of their skills were to be influenced. Studies showed that the students' non-effective exposure to the clinical learning environment had increased dropout rates. Some nursing students had left the profession as a result of challenges they faced in the clinical settings. ${ }^{39}$

From current study findings, it can be inferred that nursing schools in Zambia had postponed or rescheduled exams and introduced alternative methods of learning such as online and home-based assessments. The common challenges emerging included issues of fairness and the feasibility of alternative assessments. Noting a distinct trend towards online assessments, it was noted that not all courses and competencies can be assessed online. Similarly, it was reported that there have been challenges regarding the methods of summative assessments using online methods. ${ }^{32}$ Findings on the effectiveness of online infrastructure suggest that most students strongly disagreed $(40.3 \%)$ that their school has an effective e-library. The students strongly agreed $(40.3 \%)$ that some students missed assessments and lectures due to poor internet access and they strongly disagreed $(36.7 \%)$ that their school has effective wireless facilities to be used for online learning. Goh et al reported that the introduction of online learning was a positive way for continuity of learning, despite the many challenges that technology comes with. ${ }^{40}$ Some University and College students have little or no access to internet services, making it difficult for them to learn during the COVID-19 pandemic. ${ }^{34}$

Similarly, it has been reported that successful and sustainable e-learning implementation continues to remain a challenge, particularly in Information and communications technology (ICT) challenged environments such as rural areas. ${ }^{41}$ This literature acknowledges the fact that there is a disparity in terms of access to ICT in different geographical locations within a country. A study conducted in Bangladesh reported that respondents explained that online education would not be the best way to use for teaching-learning in the context of Bangladesh as many universities did not have enough resources for running online education urgently. ${ }^{30}$ The participants also said that while some teachers tried to take online classes on their initiatives, they faced some issues regarding virtual learning courses on online platforms. Some of them had no electronic devices such as computers, laptops, smartphones, or tablets to take part in online classes and no internet access at home.

Arguably, in midst of the implementation of the COVID19 guidelines in Zambia, learning institutions were depending on the online modes of teaching to maintain continuity of education. Schools were launching apps, conducting classes over Google Hangouts or Zoom, and sending interactive worksheets and videos for learning. Even though internet-based teaching was the most appropriate stop-gap arrangement, it had highlighted the inequalities in the education system. ${ }^{36} \mathrm{~A}$ majority of the student population were being left out in the pursuit of basic education, especially those facing financial challenges and lack of internet access. ${ }^{33,34}$

A policy brief by the United Nations policy eluded that in ensuring learning continuity during the time of school closures, it became a priority for governments all over the world to turn to ICT, requiring teachers to move to online delivery of lessons. ${ }^{42}$ In various countries, some ICT modalities have been used more than others, depending 
on education level, with variability across regions. In areas with limited connectivity, governments had used more traditional distance learning modalities, often a mix of educational television and radio programming, and the distribution of print materials. Relatively few countries were monitoring the effective reach and use of distance learning modalities. However, estimates indicated variable coverage: distance learning in high-income countries covers about $80-85$ per cent, while this drops to less than 50 per cent in low-income countries. This shortfall was largely attributed to the digital divide, with the disadvantaged having limited access to basic household services such as electricity; a lack of technology infrastructure; and low levels of digital literacy among students, parents, and teachers. All challenges with regards to the use of technology for online learning must be taken into consideration. ${ }^{42,43}$

With regards to the findings on the measures to be put in place to remedy the effects of COVID-19 on nursing education, final year students indicated that their schools should provide face masks $(51.9 \%)$ and hand sanitisers (46.8\%). Besides, most students $(40.5 \%)$ suggested that their lecturers should study refresher courses in ICT and $(49.2 \%)$ recommended that the schools should improve their e-library. According to the United Nations report, many educators lack basic ICT skills. ${ }^{42}$ Many challenges may arise when students are exposed to a different mode of learning. ${ }^{44,45}$ However, introducing students to online learning and assessments ensures that they continue learning and never be delayed in their academic progression. ${ }^{46}$ Blended learning has been found to very effective and allows continuity of learning during physical school closures. ${ }^{47-50}$ Hence, there is a need for urgent steps to be taken to provide technical resources and improve internet connection for ensuring uninterrupted online education. ${ }^{30}$ This will in turn fulfil the education needs of tertiary level students in this period of the COVID-19 pandemic.

\section{Strengths and limitations}

This study is essential as it provided information on the challenges that were being first by nursing students during the first wave of the COVID-19 pandemic. It was the first ever study to be conducted in Zambia on the impact of COVID-19 of COVID-19 on the academic activities of nursing students. Therefore, the findings of the study are cardinal in developing strategies that addresses the negative impact of COVID-19 on the academic activities of students.

Conversely, the study had some limitations. The study was a cross-sectional study that was conducted among final-year nursing students. Hence, the findings cannot be generated to the other student populace.

\section{CONCLUSION}

The COVID-19 pandemic has drastically contributed to nursing training institutions' failure to complete the course work coverage and late administration of examinations for final year students. The most critical aspect was the inability of the final year students to comprehensively do clinical placements which rendered the training more theoretical. The online infrastructure at the nursing training schools was not effective in supporting effective learning and assessments during the COVID-19 pandemic. It was also established that there was an urgent need to improve the competencies of lecturers and students in the areas of ICT. Learning institutions must put in place measures to mitigate the impact of COVID-19 on the academic activities, mental health and extracurricular activities of students. Therefore, the incorporation of blended learning in the nursing training curriculum is very vital and will help avoid certain challenges in future.

\section{ACKNOWLEDGEMENTS}

Authors are thankful to the University of Zambia elibrary for providing access to the referencing materials used in this article. Authors are also thankful to the participants and learning institutions where we collected data from.

\section{Funding: No funding sources \\ Conflict of interest: None declared}

Ethical approval: The study was approved by the Institutional Ethics Committee

\section{REFERENCES}

1. Shereen MA, Khan S, Kazmi A, Bashir N, Siddique R. COVID-19 infection: Origin, transmission, and characteristics of human coronaviruses. J Adv Res. 2020;24:91-8

2. Adhikari SP, Meng S, Wu YJ, Mao YP, Ye RX, Wang QZ, et al. Epidemiology, causes, clinical manifestation and diagnosis, prevention and control of coronavirus disease (COVID-19) during the early outbreak period: a scoping review. Infect Dis Poverty. 2020;9:29.

3. Mudenda S, Witika BA, Sadiq MJ, Banda M, Mfune RL, Daka V, et al. Self-medication and its Consequences during \&amp; after the Coronavirus Disease 2019 (COVID-19) Pandemic: A Global Health Problem. Eur J Environ Public Heal. 2020; 5(1):em0066.

4. Cao W, Fang Z, Hou G, Han M, Xu X, Dong J, et al. The psychological impact of the COVID-19 epidemic on college students in China. Psychiatry Res. 2020; 287(5):112934-40.

5. Kaul V, Gallo de Moraes A, Khateeb D, Greenstein Y, Winter G, Chae J, et al. Medical Education during the COVID-19 Pandemic. Chest. 2020;10(3):58-65. 
6. Khanal P, Devkota N, Dahal M, Paudel K, Joshi D. Mental health impacts among health workers during COVID-19 in a low resource setting: a cross-sectional survey from Nepal. Global Health. 2020;16:89.

7. Xiao H, Shu W, Li M, Li Z, Tao F, Wu X, et al. Social distancing among medical students during the 2019 coronavirus disease pandemic in china: Disease awareness, anxiety disorder, depression, and behavioural activities. Int $\mathbf{J}$ Environ Res Public Health. 2020;17(14):1-13.

8. Kedraka K, Kaltsidis C. Effects of the Covid-19 Pandemic on University Pedagogy: Students' Experiences and Considerations. European Journal of Education Studies 2020;7:8.

9. Mustafa N. Impact of the 2019-20 coronavirus pandemic on education. Int J Health Pref Res. 2020; 5(20):31-44

10. Conto AC, Akseer S, Dreesen T, Kamei A, Mizunoya S, Rigole A. COVID-19: effects of school closures on foundational skills and promising practices for monitoring and mitigating learning loss. Innocenti Work. 2020;2020(13):1-30.

11. Onwusuru MI, Ogwo BA. Cloud-based portal for professional development of technology educators in Nigeria and the emerging virtual workplace. Int J Arts Technol Edu. 2019;11(1):1-17.

12. Hoffman JA, Miller EA. Addressing the consequences of school closure due to covid-19 on children's physical and mental well-being. World Med Health Policy. 2020;10:1002.

13. Dewart G, Corcoran L, Thirsk L, Petrovic K. Nursing education in a pandemic: Academic challenges in response to COVID-19. Nurse Educ Today. 2020; 92:104471.

14. Rosário R. COVID-19 and Schools Closure: Implications for School Nurses. J School Nurs. 2020; 36(4):241-2.

15. Ilankoon, IMPS, Kisokanth G, Warnakulasuriya SSP. COVID-19: Impact on undergraduate nursing education in Sri Lanka. J Public Health Res. 2020; 9(s1):1-3.

16. Alfano V, Ercolano S. The Efficacy of Lockdown against COVID-19: a cross-country panel analysis. App Health Eco Health Policy. 2020;18(4);509-17.

17. Krishan K, Kanchan T. Lockdown is an effective "vaccine" against COVID-19: A message from India. J Infect Develop Countries. 2020;14(6):545-6.

18. Sahu P. Closure of universities due to coronavirus disease 2019 (COVID-19): Impact on education and mental health of students and academic staff. Cureus. 2020;12(4):4.

19. Earn DJD, He D, Loeb MB, Fonseca K, Lee BE, Dushoff J. Effects of school closure on incidence of pandemic influenza in Alberta, Canada. Ann Internal Med. 2012;156:173-81.

20. Kawano S, Kakehashi M. Substantial impact of school closure on the transmission dynamics during the pandemic flu H1N1-2009 in Oita, Japan. PLoS ONE. 2015;10(12):e0144839.
21. Luca GD, Kerckhove KV, Coletti P. The impact of regular school closure on seasonal influenza epidemics: a data-driven spatial transmission model for Belgium. BMC Infect Dis. 2018;18:29.

22. Wu JH, Tennyson RD, Hsia TL. A study of student satisfaction in a blended e-learning system environment. Computers Edu. 2010;55(1):155-64.

23. UNESCO. COVID-19 Educational disruption and response. Available at: https://en.unesco.org/news/covid-19-educationaldisruption-and-response. Accessed on 20 February 2021.

24. Chandasiri O. The COVID-19: Impact on Education. J Asian African Social Sci Human. 2020;6:37-42.

25. Meo SA, Abukhalaf A, Alomar A, Sattar K, Klonoff DC. COVID-19 pandemic: impact of quarantine on medical students' mental wellbeing and learning behaviors. Pak J Med Sci. 2020;36:S43-8.

26. Waseem M, Aziz N, Arif MU, Noor A, Mustafa M, Khalid Z. Post-traumatic stress of COVID-19. Pak Armed Forces Med. 2020;70:45-9.

27. Coronavirus disease 2019 (COVID-19). Available at: https://www.who.int/docs/default-

source/coronaviruse/situation-reports/20200319-sitrep59-covid-19.pdf?sfvrsn=c3dcdef92. Accessed on 20 February 2021.

28. Mudenda S. Coronavirus disease (COVID-19): a global health problem. Int J Pharm Pharmacol. 2020; 4(1):1-2.

29. Kasanga M, Mudenda S, Gondwe T, Chileshe M, Solochi B, Wu J. Impact of COVID-19 on blood donation and transfusion services at Lusaka provincial blood transfusion centre, Zambia. Pan Afr Med. J 2020;35(2):74.

30. Sushmita D, Marzia KS. The Impact of COVID-19 Pandemic on Tertiary Education in Bangladesh: Students' Perspectives. J Social Sci. 2020;8:9.

31. Joskow J, Yamane T. Statistics, an introductory analysis. J Am Stat Assoc 1965;60(310):678.

32. Shehata MH, Abouzeid E, Wasfy NF, Abdelaziz A, Wells RL, Ahmed SA. Medical Education Adaptations Post COVID-19: An Egyptian Reflection. J Med Edu Curr Dev. 2020;4(5):45-9.

33. Mudenda S, Mukosha M, Mwila C, Saleem Z, Kalungia AC, Munkombwe D, et al. Impact of the coronavirus disease on the mental health and physical activity of pharmacy students at the University of Zambia: a cross-sectional study. Int $\mathrm{J}$ Basic Clin Pharmacol. 2021;10:324-32.

34. Mudenda S, Zulu A, Phiri MN, Ngazimbi M, Mufwambi W, Kasanga M, Banda M. Impact of coronavirus disease 2019 (COVID-19) on college and university students: a global health and education problem. Aquademia. 2020;4(2):ep20026.

35. Charles NE, Strong SJ, Burns LC, Bullerjahn MR, Serafine KM. Increased mood disorder symptoms, perceived stress, and alcohol use among college students during the COVID-19 pandemic. Psychiatry Res. 2021;296:113706. 
36. Gonzalez T, de la Rubia MA, Hincz KP, ComasLopez M, Subirats L, Fort S, et al. Influence of COVID-19 confinement on students' performance in higher education. PLoS ONE. 2020;15(10): $\mathrm{e} 0239490$.

37. Burgess S, Sievertsen HH. The impact of COVID-19 on education. Available at: https://voxeu.org/article/ impact-covid-19-education. Accessed on 20 February 2021.

38. Aslan H, Pekince H. Nursing students' views on the COVID-19 pandemic and their perceived stress levels. Perspect Psychiatr Care. 2020;10:12597.

39. Vela K. Using Slack to communicate with medical students. J Med Libr Assoc. 2018;106:504-7.

40. Goh P, Sandars J. A vision of the use of technology in medical education after the COVID-19 pandemic. MedEd Pub. 2020;9(1):49.

41. Awidi IT. E-learning implementation strategies for an ICT-challenged environment: case of the University of Ghana, Legon. Available at: https://ro.ecu.edu.au/ theses/573/. Accessed on 20 February 2021.

42. Education during COVID-19 and beyond. Available at: https://unsdg.un.org/resources/policy-brief-education-during-covid-19-and-beyond. Accessed on 20 February 2021.

43. Subedi S, Nayaju S, Subedi S, Shah SK, Shah JM. Impact of e-learning during COVID-19 pandemic among nursing students and teachers of Nepal. Int J Sci Healthcare Res. 2020;5(3):9.

44. Chan KS, Zary N. Applications and challenges of implementing artificial intelligence in medical education: integrative review. JMIR. 2019;5(1): e13930.

45. Pokhrel S, Chhetri R. A literature review on impact of COVID-19 Pandemic on teaching and learning. High Edu Future 2021;8(1):133-41.

46. Martin F, Ritzhaupt A, Kumar S, Budhrani K. Awardwinning faculty online teaching practices: Course design, assessment and evaluation, and facilitation. Internet Higher Edu. 2019;42:34-43.

47. Amir LR, Tanti I, Maharani DA, Wimardhani YS, Julia V, Sulijaya B, et al. Student perspective of classroom and distance learning during COVID-19 pandemic in the undergraduate dental study program Universitas Indonesia. BMC Med Educ. 2020;20:392.

48. Daniel SJ. Education and the COVID-19 pandemic. Prospects. 2020;49:91-6.

49. Mukhtar K, Javed K, Arooj M, Sethi A. Advantages, limitations and recommendations for online learning during COVID-19 pandemic era. Pak J Med Sci. 2020;36(S4):S27-31.

50. Zhang W, Wang Y, Yang L, Wang C. Suspending classes without stopping learning: China's education emergency management policy in the COVID-19. J Risk Finance Manage. 2020;13(3):55.

Cite this article as: Mwila K, Kalolo F, Mudenda S, Hikaambo CN. Impact of COVID-19 on academic activities of final year nursing students: a Zambian reflection. Int J Basic Clin Pharmacol 2021;10:80612. 